\title{
Ukrainian Religious Advertising: the evolutionary dynamics of semiotic code
}

\author{
Klymentova Olena \\ Doctor of Philology, Professor of the Department of Stylistics and Linguistic Communication Taras Shevchenko \\ National University of Kyiv, Institute of philology, Ukraine.
}

\begin{abstract}
Religious advertising is a new phenomenon in the Ukrainian media space. Nowadays it is obvious that at the initial stage of development, religious advertising used to function as an information board. Starting from 2019 to the present, it has been found right in the middle of political battles as a public platform that represents the idea of Independent Ukrainian Church. Manipulative influence was based on verbalizing the attention-drawing correlation of the concept UKRAINIAN CHURCH and the concept INDEPENDENT UKRAINIAN STATE. Religious advertising with a strong political component has become part of the conflict discourse, and its influential experience is qualified by experts as manipulation. In religious advertising with social convergence the creative impulse is formed primarily by verbal manifestations of a new cognitive style in the processes of obtaining religious experience. The new features are represented in God's speech behavior, speech style, communicative situations with His participation, role distribution, genre preferences and the emotional background of communicative interactions. There are also specific national features of religious advertising that constitute for Ukrainians the core of their spiritual priorities. In fact, Ukrainian religious advertising strives to balance between short-term political interests and long-term social interests along with eternal, timeless values. In this context, the phenomenon of religious advertising is a convincing example of communicative dynamism.
\end{abstract}

Keywords: dynamism; God's linguistic personality; substitution

\section{Introduction}

Religious media is a relatively new object of scientific research, which leads to scholars' growing interest in the mass-media phenomenon. According to M. Petryshkevich, religious communication has a complex structure, it is associated with religious traditions and canons, but it must also adapt to the dictates of time. Technical means of transmitting information, namely the press, radio, television, the Internet, new media, cause transformations in religious communication. Manifestations of religiosity are becoming more varied, bringing secular and religious communication closer together. Modern religious media actively interact with each other and create a kind of symbiosis that helps to increase the influence of mass communication on a particular person. The new media, especially social networks with their enhanced dialogicity and mass audience, are the closest to the essence of religious communication. The radio and the press are different in that they preserve their oneway communication patterns. They maintain their communicative traditions and are a continuation of classical religious communication, since they are based on the spoken or 


\section{2nd world conference on research in SOCIAL SCIENCES}

written word. Television religious discourse offers coverage the mass audience and the need for unification of communication. The use of digital media draws religious issues into the field of mass communication and destroys the spatial, social and religious boundaries between people (Petrushkevych, 2018). That is why the signs of programming character were put into basis of media linguistic analysis of religious advertising.

It is necessary to note that religious advertising is a completely new phenomenon in the Ukrainian media space. However, the emergence of religious advertising is a natural course of events. It was predicted by researchers of discourse. Thus, the experts at Freedomart argue that religious communication in general and brand communication as a form of advertising representation in the modern socio-cultural sphere have many features in common. Some scholars develop this point of view and propose several explanations which reflect this peculiarity. First, the current situation may be the result of the advertising integration process in all areas of social reality. Second, it may be connected with the fact that religion has consciously or unconsciously been using marketing techniques from the very beginning of its existence. After all, advertising in the form of announcements of heralds, posters and albums existed as far back as in Ancient Rome. At present, religious institutions borrow from advertising many new means to exert influence on their audience. Third, what is happening can be explained as a necessity caused by modern realities when consumer loyalty can be secured only with the help of advertising (Dmitrieva \& Shusharin, 2013).

The problem that remains unresolved lies in that religious discourse is undergoing a radical change. At the current stage of development, religious discourse in Ukraine is being transformed simultaneously by several sources of influences. This is primarily an institutional renewal, which has diversified confessional feelings of believers and increased the tendency to socio-political correction of processes in the religious sphere, including the field of communication. Nowadays it is obvious that at the initial stage of development, religious advertising used to function as an information board. Starting from 2019 to the present, it has been found right in the middle of political battles as a public platform that represents the idea of Independent Ukrainian Church. Under the current circumstances, the communicative peculiarity of religious advertising is defined by the new semiotic code as a system of strict guidelines, rooted in both political propaganda and religious values.

At the same time, religious communication has acquired innovative features, typical of the mass media advertising. The dynamics of semiotic code, determined both by extralinguistic and linguistic factors, create new perspectives for the research into religious concepts in general and their postmodern representations in particular. The range of expressive means that provides the basic religious ideas is changing noticeably. The surge of linguists' interest in the media segment of religious communication can be observed nowadays because nowadays modern mass media technologies of transmitting, receiving and consolidating the experience of communication with God are being used as the primary sources of information. Lack of knowledge about the media literacy can lead to communicative manipulations. Meanwhile, the linguistic profiles of the whole manipulative communicative process are rather hard to identify. In general, verbal manipulation is manifested in the texts which correlate with lies, deception, aggression, conflict, invective, fiction, illusion, fake, etc. Yet, it should be noticed that peculiarities of communicative influence are distinguished in different informative spheres and in the religious space in particular. When it concerns religious advertising, we mainly associate it with verbal suggestion. Consequently, understanding the programming nature of religious advertising expands knowledge about the mass media personality as object of religious communication. 


\section{2nd world conference on research in SOCIAL SCIENCES}

Unfortunately, scholars pay insufficient attention to hybrid types of influence in modern religious communication and its innovative genres in particular. From our point of view, religious advertising is an important factor to stratify values that, on the one hand, shape one's spiritual life and, on the other hand, are used through mass media as means of influence in the modern society.

We can view religious advertising as a media practice that transforms a religious message from an archaic language into a modern one so that the recipient may perceive it as a personal experience of communion with God. New advertising goals impose new requirements on the creators of advertising, in particular on media literacy. It is vital to remember that in religious communication we can distinguish between pathogenic and therapeutic text technologies, productive and habitual manipulations, explicit meanings and hidden intentions, established conventions, symbolic and hybrid codes and other aspects of media literacy.

And finally, it is our deep belief that prospects for the development of the media genre lie in the anthropocentric understanding of the phenomenological essence of religious advertising which can be actualized only in an active dialogue with society. The goal of the study is to perform of the evolutionary dynamics of semiotic code of religious advertising that is used on the territory of Ukraine.

\section{Methodology}

The research applies the methodology of interactional sociolinguistic (Gumperz, 2003) which is grounded on the theory of situational inference in the anthropological perspective, i.e., the motivational nature of language is considered in its connection with cultural and social factors and is related with the theory of frame's interaction. The methodology is based on a set of discourse analysis methods aimed at identifying and analyzing situational meanings. The ultimate objective of the study lies in exploring discursive strategies. The research draws on the approach put forward by Erving Goffman (Goffman, 1974): the Canadian-American sociologist views an interaction frame as the matrix of some events and a set of roles. This model of interaction is created in interactions and perceived differently by each participant. Interactional framing is close to the idea of "type of activity" or speech activity. Contextual framing correlates with interpretation framing. According to Goffman, an interaction consists of frames. The behavior of each communicator is associated with a certain scenario, while the dynamic of a role is regulated by behavior patterns expected from participants of various statuses.The methodology of the research is based on modern approaches to study linguistic programming. At the same time, contemporary branches of philological studies (such as sociolinguistics, cognitive linguistics, political linguistics, psycholinguistics, linguistic pragmatics, discourse linguistic, etc.) also include research into communicative strategies in their correlation with verbal influence.

\section{Results and Discussion.}

Creative impulse of religious advertising and its communicative peculiarities are based on strong convergent tendencies that correspond to political, social and marketing discourses. 


\section{2nd world conference on research in SOCIAL SCIENCES}

19-21 March, 2021

Budapest, Hungary

\section{1. Religious advertising and political convergence}

Within the political project of former Ukrainian president P. Poroshenko (2019), religious advertising was used to introduce and promote the concept INDEPENDENT UKRAINIAN CHURCH. The new semiotic code was created within the advertising campaign and was developed during the race for presidency. That was an ideological code where the ideologeme of state independence and the religioheme of church independence were used in the diffusive interaction on the idea of Ukrainian statehood. In our case, national identity, political identity and confessional identity were united within the framework of the ideological code (Stepanov, 2012).

Then, why is it religious advertising? First of all, because Ukrainian priests and believers were the objects of influence of this advertising (Fig. 1). Religious beliefs play a significant part in shaping their social behavior. Thus, in modern Orthodox identity, the cultural factor tends to dominate. Orthodoxy is moving towards cultural identity due to the ideological vacuum in society, weak civic awareness, challenges of globalization and the Soviet atheistic heritage (Boreyko, 2017).

Figure 1. 'Thomos is for Ukraine!'

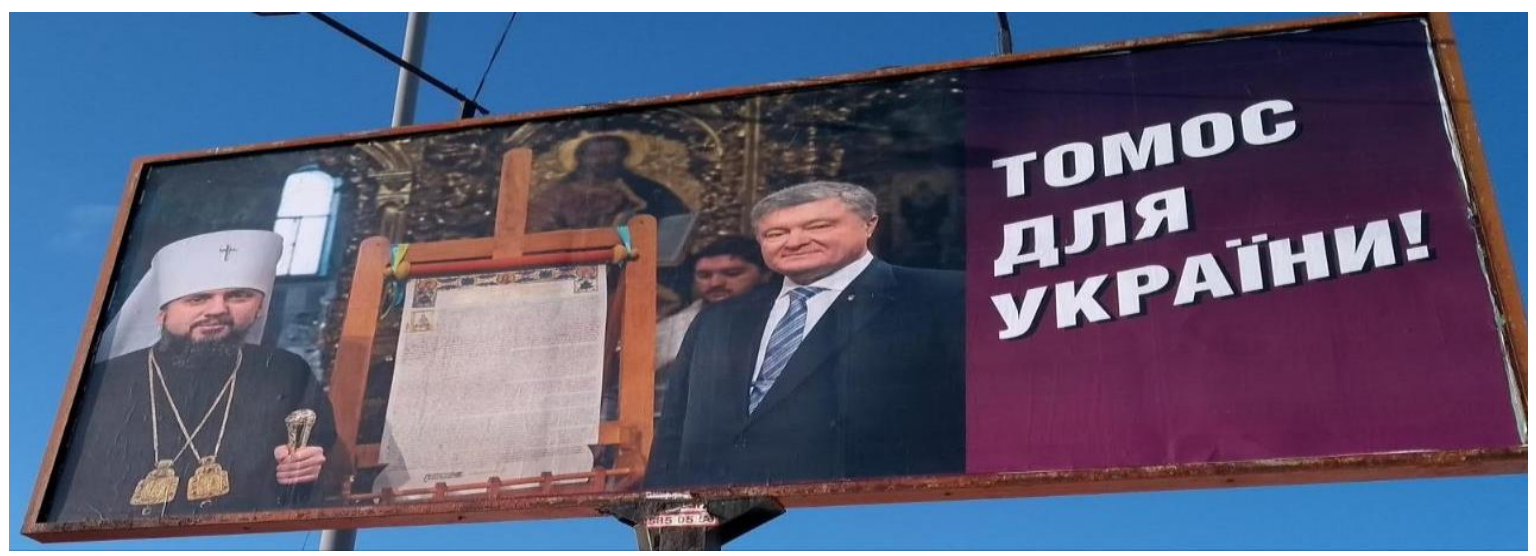

Photo from: vybory.pravda.com.ua

It is necessary to note that Ukraine is a predominantly Christian country. Under current conditions, the tendency to a high level of declared religiosity of the population persists (Boreyko, 2017). Religion is an element of culture that pervades every aspect of a society. It should be noted that cultural dimensions are very dynamic in a society, but religious tenets form a stable and static social basis. This stability and manageability attracts politicians who want support from a stable and manageable religious electorate (Fig. 2). 


\section{2nd world conference on research in SOCIAL SCIENCES}

Figure 2. 'We are Ukraine. The local church is the key to independence. Petro Poroshenko'

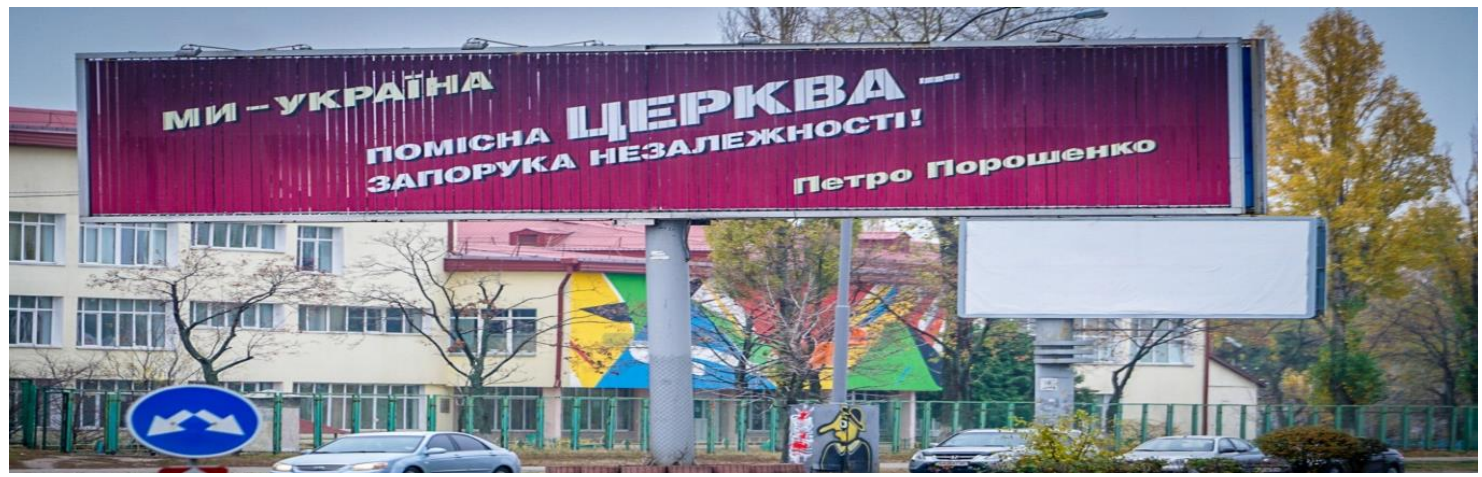

Photo from: starovina.LiveJournal.com

According to religious marketing researchers Kim Shyan FAM, David S. Waller, and B. Zafer Erdogan, ethical and moral components in advertising are very important to Christians. The scientists write in the influence of religion on attitudes toward the advertising of controversial products: "Christianity bases its ethical system on the Jewish covenant, but focuses on its spirit, not ritual law. As a result, the Ten Commandments and the prophets carry most ethical force. Jesus represents counsel of compassion, meekness, a hunger for righteousness, mercy, purity of heart, peace, and faith in the face of persecution. It takes Old Testament law such as the prohibition against killing, and applies it deeply and broadly so that a hostile thought almost becomes a sin" (Fam et al., 2004).

Figure 3. 'We are Ukraine. The Army defense our land. The language defenses our heart. The Religion defenses our soul. Petro Poroshenko'

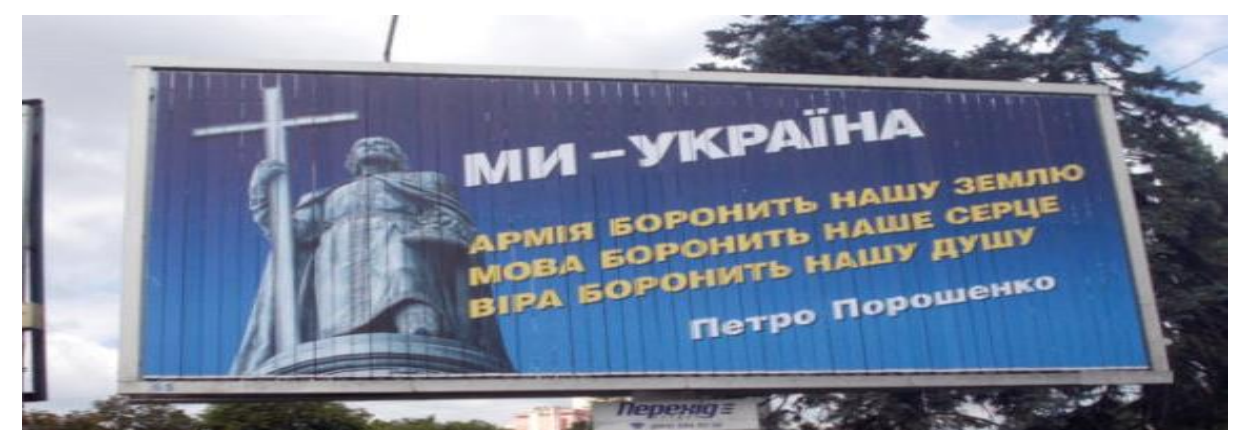

Photo from: vybory.pravda.com.ua

Ukrainians have also shown increased attention to the intentional level of this hybrid advertising and recognized the manipulation. This draws linguists' attention to language markers of manipulation. Manipulative influence was based on verbalizing the attentiondrawing correlation of the concept UKRAINIAN $\mathrm{CHURCH}$ and the concept INDEPENDENT UKRAINIAN STATE. As a result, a new version of Ukrainian identity was suggested to the citizens of Ukraine (Fig. 3). This understanding of identity has become a major epistemology of Ukrainian conflict discourse. The hybrid advertising (both political and religious) helped deliver the politically important information about the ideological 


\section{2nd world conference on research in SOCIAL SCIENCES}

confrontation between Ukraine and Russia that marks the present stage of their relations. However, the demarcation line was drawn in the spiritual sphere. As a result, the new strategic narrative reconstructed the 'we/our vs they/their' opposition.

Figure 4. 'Thomos 2018'

Figure 5. 'For where is your treasure, there your heart will be! Lipetsk confectionery factory "Roshen". Matthew 6.21'

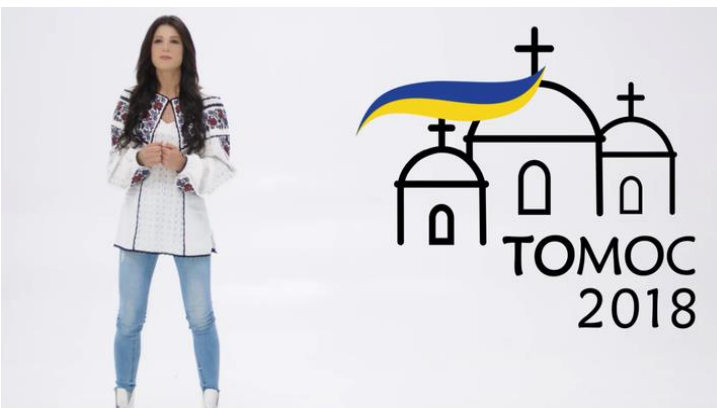

Photo from: spzh.news

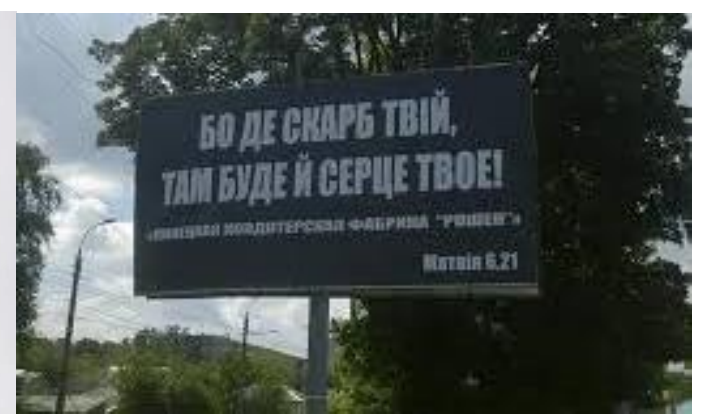

Photo from: politeka.net

Thus, the new connotations of axiological (or evaluative) components in the structures of the analyzed concepts formed the new evaluative meanings associated with the opposition 'war vs peace', 'enemy vs patriot', 'freedom, democracy vs slavery', 'past vs future', 'fake vs truth', 'Russian language vs Ukrainian language', 'Russian Orthodox vs Ukrainian Orthodox', 'righteous person vs sinner', 'believer vs unbeliever', etc. In this case, both the ideological worldview and the religious worldview merge into the new worldview, written in black and white mental codes with the same pragmatic potential (Fig. 4).

Within this approach, the concept of UKRAINIAN CHURCH has acquired some signs of socio-semantic concepts that correlate with certain political references in particular. In the textual representations, such concepts are loaded with a believer's self-identification followed by their further identifying with a group that has developed its own ideological categorization, on the one hand. On the other hand, the meaning is determined by the religious references and confessional arguments. In addition, these three components, namely, self-identification, group identity, and ideological categorization, are combined with marketing inventory that controls the believer's interpretations of symbols and signs within manipulative communicative strategies.

The next type of religious advertisement is of an intertextual nature and is also constructed according to the manipulative strategies and tactics of political discourse (Fig. 5). Speaking about the close connection of such advertising with political aims, we rely on the key values in the Ukrainian worldview. The attitudes to the army, language and faith are transformed into imperative for Ukrainians. All these values stem from cognitive processes of conceptualizing the Ukrainian reality and its religious spectrum in particular. Fighting in some regions of Ukraine, conflicts over language, the struggle of churches for parishioners have caused changes in lives of Ukrainians and forced them to reconsider their life priorities. The advertising representations appeared in the context that explicated the binary oppositions mentioned above, which, in its turn, actualized Ukrainians' values. However, the presence of the president's name in the advertisement changed the semantic vector of text decoding. 


\section{2nd world conference on research in SOCIAL SCIENCES}

19-21 March, 2021

Budapest, Hungary

In this case, the oppositional semiotic principle was used in other religious advertisements. The tendency to fuse political and religious meanings in an advertising text for the sake of ironic modalities is represented in the text that appeared in Cherkassy: "For where is your treasure, there your heart will be!" Lipetsk confectionery factory "Roshen". Matthew 8.21. (Fig. 5)

The purpose of the advertisement lies in eroding Poroshenko's political image. This advertisement is a kind of provocation, antiadvertising; it attempts to draw the target audience's attention to the declarative nature of the presidential program and spurs emotional protest against his position. The allusion to the Sacred text is used as subtle yet easy-todecode hint at the President's financial well-being in the state with weak economy and poor people. The text Lipetsk confectionery factory "Roshen" is the implicit reference to Poroshenko, who has some business interests in the country-aggressor of Ukraine. Hence, there is an obvious verbalization of such values as Goodness, God and Truth, Honour and money. The advertisement employs the communicative tactic of exposing double social standards. The allusion to the Holy Scripture as a specific form of intellectually and emotionally marked continuum which correspond to God and Truth is quite explicit. There are such key words in this part of the mass media message as treasure and heart. The word treasure is used in its primary meaning, but the word heart is actualized in its figurative meaning the essence.The complex stylistics of the advertisement based on the specific connection of the sacral text rhetoric with the speech nominative sentence: "Lipetsk confectionery factory "Roshen"" determines effect of the protest perception. The interpretation frame of the advertising message is also based on the oppositional-semiotic principle and is realized as a conflict of Goodness and evil, Truth and falsehood that the advertisement implicitly correlates with the President's activity.

The author's intentions are objectified as a polycode text which includes three semantic components for values categorization: religious, political and moral. Among various types of communicative models, it is the inferential model that assumes that when communicators are interpreting or receiving a message, the informative intention they must infer or recognize is what their interlocutor wanted to communicate or share with them (ScottPhillips, 2015). Within the framework of this approach, different popularized versions of advertising perlocutions were created in the Ukrainian media sphere. As a result, the frequency of lexemes that verbalize the UKRAINIAN CHURCH concept in the political slogans of then-president Poroshenko (for example, "Army, Language, Faith!", "The church is our civilization right!", "The tomos is our historical choice!"), its functional encumbrance in the program manifestos of the players (Local Ukrainian) became a characteristic feature of the Ukrainian presidential campaign in 2019. So, the means of expressing positive or negative attitudes, verbalization of such concepts as GOOD, EVIL, the categories of "owe/our" and "they/their" were implemented into the manipulative strategy of influence on the electorate. In this case, "totalitarianism" (as it is interpreted by Kaftandzhiev (Kaftandzhiev, 2005) of political propaganda and "totalitarianism" of religious ideology merge to produce the technology of verbal influence. However, we can make the conclusions that this advertisement did not meet the majority's expectations.

\subsection{Religious advertising and social convergence}

In our view, convergence to the social problematic is the most natural for religious advertising. At present, there are two tendencies to reproduce information about God in religious communication. The first is the conservative direction, related with the content of 


\section{2nd world conference on research in SOCIAL SCIENCES}

canonical ideas, and the second is the dynamic trend to update the communicative code in accordance with the general tendency towards informative interaction. It has become the major research topic for media linguistics in recent years to solve this contradiction by setting up new standards of understanding the functionality of religious messages. In our opinion, achieving any pragmatic goals in modern religious media is impossible without promoting the development of a new cognitive style adapted to the general media specifics and formed according to the innovation of technologies and current people's needs.

Figura 6. 'Jesus blesses travelers'

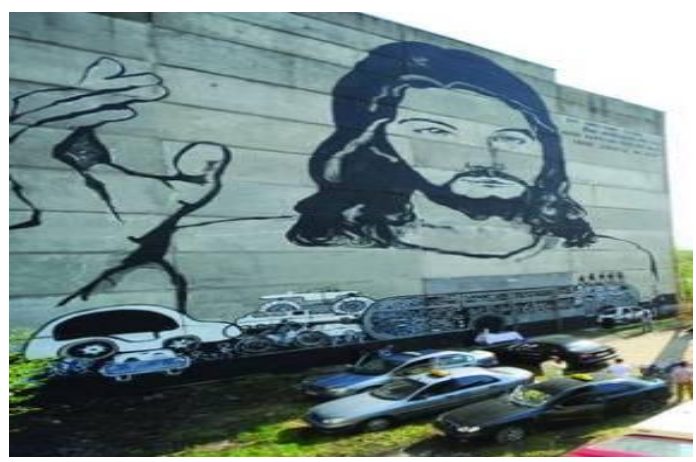

Photo from: https://credo.pro/2011/04/4433
Figura 7. 'Let's meet on Sunday ... God'

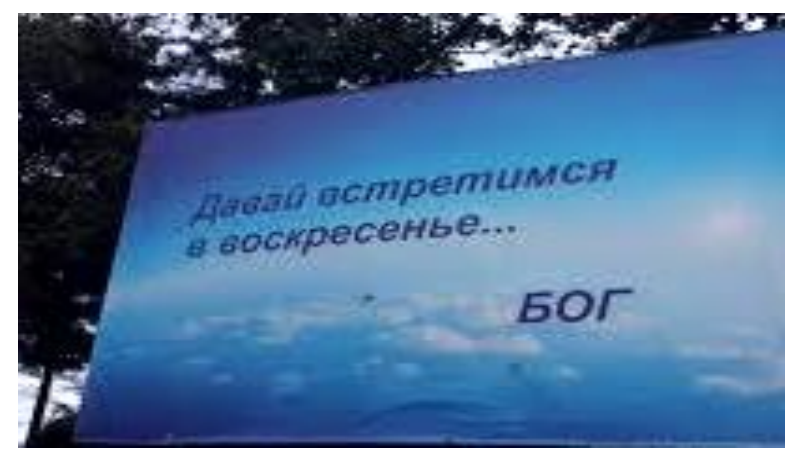

Photo from: vlasti.net/news/210827

Modern tendencies in advertising text building are enriched with such a new category as a "narrative mask" that is created according to a concrete situation and speech behavior of different narrators. It should be noted that religious registers of communication with God were determined by the sacred textual tradition and canonical conventions. Within the framework of traditional approaches, we can define the following narrative masks: "Lord", "Father", "Fair Judge", "Creator", etc. In such a case, a narrator can be represented with help of anthropic visualization and appeal to the Sacred Text. There are cases when we can see such religious advertising in Ukraine (Fig. 6).

Another approach is connected with the process when adopting patterns of modern everyday conversations helps to substitute for the religious reality. Within the framework of social convergence, creative potential of religious advertising is explicated by a deviation from standards of religious communication which represents the substitution for God.

In our opinion, religious advertising can serve as convincing example of the dynamic matrix that complements the static matrix, as they are defined by Pocheptsov (Pocheptsov, 2011). In this regard, linguistic analysis should focus on the new techniques to refer to the distinct concepts "we/our" - "they/their" as they are expressed in religious advertising.

Besides, in accordance with these approaches, the function of the main correlates of meaning "OWN" is embodied by characteristics of God's linguistic personality which corresponds to the national worldview.

According to Dubchak's viewpoint expressed in his Conceptual opposition „WE/OUR" -,,STRANGER" in the Ukrainian language model of the world, the core of concept 'WE/OUR' is formed by the basic segments 'ownership', 'kinship' and 'spiritual unity'. It has three context levels. These are physical space, family space, and spiritual space.

These cognitems are very stable for the national language consciousness. They support information and value structure at all historical stages in the Ukrainian language model of the 


\section{2nd world conference on research in SOCIAL SCIENCES}

world. Cognitems 'own space', 'own faith' and 'own language' belong to its core, whereas lexical units 'usually', 'habitual' and 'normal' are on the periphery. These lexemes do not have a direct lexical meaning 'WE/OUR', but they are able to express it in context and through synonymization with the key words in relevant syntagmatic relations. The awareness of 'OUR' objects in the Ukrainian language model of the world is represented as positive or neutral (Dubchak, 2009, A).

In modern Ukrainian banner advertising, meanings are creatively represented in God's speech behavior, speech style, communicative situations with His participation, role distribution, genre preferences and the emotional background of communicative interactions. The semantic characteristics are contained mainly in the prosody of speech and the intonation model, which are determined by speech genres. Contemporary connotations arise here from the way God speaks. God demonstrates a partner style of communication, and at the same time, it is an inspiring, caring, friendly, and open talk. For example: "I love! I love! I love! God" (Fig. 8) and "Let's meet on Sunday ... God" (Fig. 7). It is necessary to note that stylistically, both of these examples are of colloquial nature. The former is a love note, and the latter is a friendly invitation. These are the so-called secondary genres (cf., not a love confession, but a love note, not a business proposal, but an utterance from an everyday dialogue). They are used primarily informal communication and marked by the background of contacts. The addressor of the advertising message is God.

The semantic code: "God is love" is used in the first text. It is actualized by the communicative tactic of emotional influence which draws on the biblical idea that correlates with one of the most fundamental human needs. The communicative tactic of emotional influence is carried out with the help of the verbal predicate with positively estimated value: love. The suggestive effect is achieved by reiterating thrice the emotionally marked regulative verb. It is known that the need to be loved is the biopsychological, social, and spiritual need of the human. Substituting the figure of God for an emphasis on love arouses in recipients' of the advertisement the pleasant feelings of high self-esteem, peace, security, care, associated with God as the subjective source of these states.

In the advertisement "Let's meet on Sunday ... God", the substitutive function is actualized by God's informal register that corresponds to the meanings "belonging". It is also developed within the frame 'God is our'. As we can see, God's communicative style corresponds to the meanings "friend" or "comrade". In this case, mental units such as acquaintance, like-minded person, colleague, accomplice, comrade, friend, brother correspond to different levels of their incorporation in 'our' circle (Dubchak, 2009, B). 


\section{2nd world conference on research in SOCIAL SCIENCES}

Figure 8. 'I love! I love! I love! God'

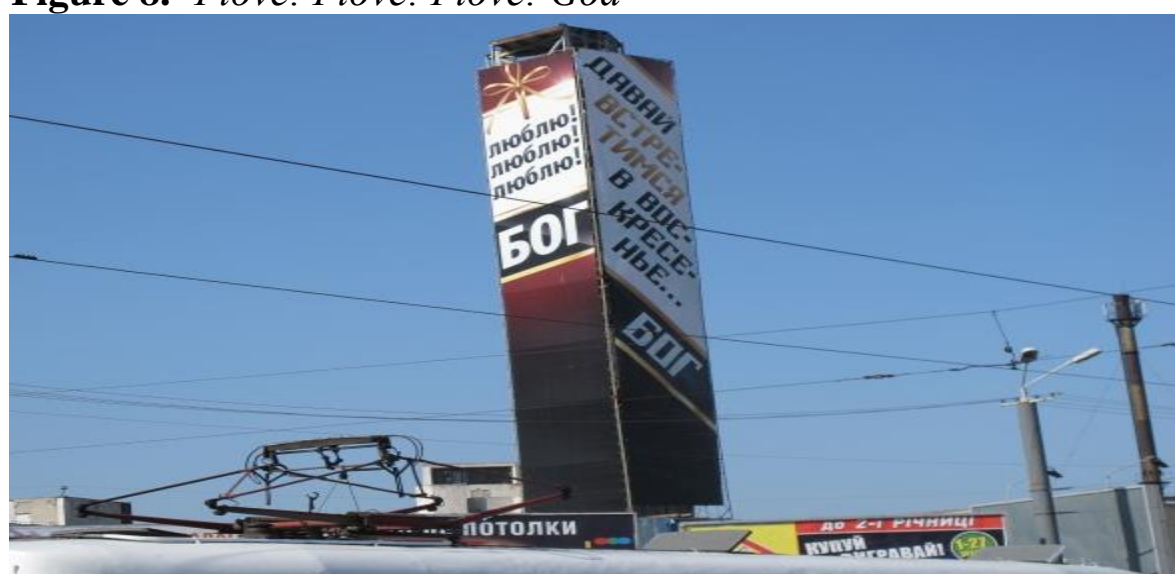

Photo from: atanoissapa.livejournal.com

The pragmatic effect of the utterance determined by the content and the form of the advertising message can certainly be interpreted in a very wide range of communicative situations. However, in our opinion, the syncretism of the ethical, cultural and religious components of the national worldview will determine perceptions of Ukrainian people. God's linguistic personality, implicitly modeled by the characteristics of "our", "close", "loving", "safe", "native", "partner", "open", "accessible", "friendly", etc., creates the basis for the appropriate identification of God, which, on the one hand, corresponds to the intentions of traditional approaches to the transmission of religious experience, and, on the other hand, modernizes the narrative content, making its style up-to-date.

In turn, violating the rules of ritual speech leads to the language play effect: God appears to participate in communication and to display the hybrid communicative behavioral model. In the advertisement, the positional role of God in human life with its behavioral standards, canonically defined, ritually fixed and rhetorically decorated by the culture of sacred text, merges with the situational role and its everyday communicative manifestations. This fact changes the nature of God's speech, because everyday speech is determined by genre forms in general. In our case, the examples belong to colloquial genres.

It should also be mentioned that in these examples genres are markers of a profane locus which, according to evaluation parameters, is in opposition to the sacred world. Thus, the nature of the communicative situation in both advertising texts indicates a contextual framework atypical for the discourse in general, since there is no differentiation between the sacred and the profane zones. The role structure of the communicative situation, nevertheless, follows the norm for religious communication where the subject of communication is God and the human acts as a silent listener. All this feeds the intrigue of the advertising representation and enhances its attention-drawing function and influence on recipients. This technique produces an illusion of the reduced distance between God and recipients. Apparently, the most effective way to establish the contact between God and the human is to use a communicative genre which is the best for close, informal, private relationships. Thus, the necessary foundation for the implementation of God image as "our" is created.

\subsection{Religious advertising and marketing convergence}

In addition, we should not forget that religious advertising is a tool of religious marketing. At the same time, it is also an innovative object of marketing linguistics, which 


\section{2nd world conference on research in SOCIAL SCIENCES}

has positioned itself as a new applied science. In this context, it is worth mentioning Mara Einstein, an Associate Professor of Media Studies at Queens College and a professor at the business school at New York University, who points out that modern marketers should be familiar with psychological methods of working with an audience. Prior to teaching, the researcher worked as a marketing executive for NBC and MTV Networks as well as for a number of major advertising agencies. She argues that "to get consumers to buy mostly unnecessary products, advertisers became experts in psychology — at first through the use of surveys and other quantitative methods, and later through more sophisticated qualitative methodologies, such as focus groups and personal interviews" (Einstein, 2007).

In this regard, the question of what religious advertising sells is objectified. In our opinion, religious discourse, and advertising in particular, must be realized through the continuous positive interaction between church representatives and consumers. Researchers point to their positive role played by religious media in the development of discourse in general. New media actively promote identity affirmation, including religious group identity; they have a pronounced humanistic aspect: religious figures, priests, who in traditional culture have always been distanced from the flock (mentors, bearers of wisdom, in fact, the voice of God) appear as ordinary people open to communication and willing to help, removes a kind of communicative fear in such an interaction (Lawrysh, 2017).

However, at the present stage of development of religious advertising conceptology, the study has revealed the significance of the self-referential model of perception (Elston, 2010) of religious experience. It should be noted that within this approach, there are remarkable differences between traditional churches and denominations (Klymentova, 2018). At the same time, despite its ambivalent nature and unconventional features, such experience can be of great value. "The heretical imperative naturally encourages individuals to go within for epistemic authority, for as the external world becomes more insecure and open to doubt, individuals seek security and certainty within themselves. This explains why the forms of religiosity that flourish today are various iterations of what I call the religion of the heart, which roots epistemic authority in subjective experience. I would therefore argue that disenchantment of the outer world has always meant a simultaneous enchantment of the inner world" (Watts, 2017). In this connection, religious advertising with the variety of verbal intimicization techniques used in mediation is recognized as the object of further research.

The research supports the views of other modern experts who believe that communication studies and religious advertising have much to offer to each other and that findings may be mutually beneficial. Marketing linguistics provides analysis of religious advertising with scientific resources that enhance the accuracy of its self-understanding as well as with effective methods to achieve the desired goals. What appears to be vital here is to establish a dialogue. In this regard, it is important to emphasize that religious marketing is based on psychographic data about hopes, needs and fears of people. In the modern Ukraine the Church institutions are able to satisfy the needs for security and respect, fear of loneliness, giving people faith in life after death, forgiveness and understanding. In fact, it is widely believed among people that religious communication is a separate informational continuum associated with the locus of God. Although the environment of religious marketing communication is getting better and a great progress has been made in new media, the road ahead is still beset with difficulties, requiring the concerted effort of various religious, political, social, cultural, educational institutions and the entire society. It is important to establish a dialogue that will fill the gaps in the Ukrainian media landscape, in accordance with modern standards of psycho-environmental informative interaction. 


\title{
2nd world conference on research in SOCIAL SCIENCES
}

\author{
19-21 March, 2021
}

Budapest, Hungary

\section{Conclusion}

The study has revealed a new phenomenon, namely religious advertising, in Ukrainian information space that used to be dominated by atheistic propaganda. To understand cognitive significance of religious advertising for Ukrainians, it is necessary first of all to identify qualitative factors of its influence on the consumers. The research has shown that religious advertising is implemented in different forms of the communicative activities of the political and religious forces. Religious advertising with a strong political component has become part of the Ukrainian conflict discourse, and its influential experience is qualified by experts as manipulation.The study of religious advertising with social convergence has revealed that the visual expression of advertising representations is very restrained. The creative impulse of religious advertising is formed primarily by verbal manifestations in which mental meanings are produced by emotional components. The dynamics of expressive means in religious advertising indicate the formation of a new cognitive style in the processes of obtaining religious experience. At the same time, within the traditional approaches to text retransmission of Sacred knowledge, the projection of the religious worldview serves as a reminder to people about the eternal values. There are not only confessional peculiarities but also specific national features of religious advertising that constitute for Ukrainians the core of their spiritual priorities. Within this trend, religious narratives correspond to the consensus formulas of various communicative spheres. Thanks to the 'storytelling metaphors', consumers reveal the problematic aspects of religious communication as a socialization activity. As we can see, epistemological potential of religious advertising has the multy-aspect nature. In fact, Ukrainian religious advertising strives to balance between short-term political interests and long-term social interests along with eternal, timeless values. In this context, the phenomenon of religious advertising is a convincing example of communicative dynamism peculiar to contemporary religious discourse, its mass media segment in particular. Within the marketing approach, the research has also shown that the process of relaying the religious system of values, including solving the unique problem of God's substitution, is successfully implemented in religious advertising.

\section{References}

Boreyko, Y. H., (2017), A. Existence dimensions of everyday life of a Ukrainian Orthodox believer, The thesis for the degree of Doctor of Philosophy in specialty 09.00.11 «Religious Studies», Kyiv, H.S. Skovoroda Institute of Philosophy of the National Academy of Sciences of Ukraine, p. 249.

Boreyko, Y. H., (2017), B. Existence dimensions of everyday life of a Ukrainian Orthodox believer, The thesis for the degree of Doctor of Philosophy in specialty 09.00.11 «Religious Studies», Kyiv, H.S. Skovoroda Institute of Philosophy of the NAS of Ukraine, p. 246.

Dmitrieva, L.M. and Shusharin, S.A., (2013). Religija and branding: aspects of interaction, Omskij nauchnyj vestnik, 4 (12), pp.78 -81.

Dubchak, O.P., (2009), A. Conceptual opposition „OWN" -,,STRANGER ${ }^{e e}$ in the Ukrainian language model of the world. Authoreferat, Kyiv, Dragomanov NPU. 


\section{2nd world conference on research in SOCIAL SCIENCES}

19-21 March, 2021

Budapest, Hungary

Dubchak, O.P. (2009), B. Conceptual opposition „,OWN ${ }^{e e}$,,STRANGER ${ }^{e e}$ in the Ukrainian language model of the world. Manuscript, Dissertation for the candidate degree in philology speciality 10.02.01-Ukrainian language. Kyiv, Dragomanov NPU.

Elston, У., (2010). Religious experience as a perception of God, Philosophy of Religion: Almanac 2008 - 2009 / ed. V.C. Shokhin /. M: Language of Slavic cultures, pp. 198 - 209.

Einstein, M., (2007). Brands of Faith. Marketing religion in a commercial age. Religion, Media and Culture series, ed. Stewart M. Hoover and Jolyon Mitch. Routledge, Taylor and Francis Group.

Fam, Kim Shyan, Waller David S., Erdogan, Zafer B., (2004). The influence of religious on attitudes towards the advertising of controversial products, European Journal of Marketing. Vol. 38 № 5/6, p. 540. [Online]. Available: www.emeraldinsight.com /0309-0566.htm

Gumperz, J., (2003). Interactional Sociolinguistic: A Personal Perspective. [Online]. Available: http: www/blackwellreference.com.

Goffman, E., (1974). Frame Analysis: An essay on the organization of experience , Cambridge, Mass.: Harvard Univ. Press.

Kaftandzhiev, Ch., (2005). Harmony in an advertising communication, Moscow, Eksmo.

Klymentova, O., (2018). Specific aspects of verbal influence in missionary sermon (on material Russian language sermons of Pastor S. Adeladga and Pastor V. Muntyan, Odessa linguistic Journal, № 11, pp. 119 -126.

Lawrysh, Y., (2017). The Church in the New Media of Ukraine: Problems and Priorities of Communication, Lviv, Company" Imperial", p. 156.

Petrushkevych, M. , (2018). Constructing religious discourse with the help of mass media, Visnyk Cherkassy university, Philosophy series, 2, pp. 53-59.

Pocheptsov, G., (2011). Communicative mind control. [Online]. Available: https://ms.detector.media/print/9286, 24.07.2011.

Scott-Phillips, T., (2015). Speaking our minds, New York: Palgrave Macmillan, p. 26.

Stepanov, V.N., (2012). Semioticheskie kody v reklamnom tekste, Analitical Culturology, [Online]. Available: https: cyberleninka.ru /article/n/semioticheskie-kody-v-reklamnom-tekste

Watts, F., (2017). Psychology, religion and spirituality: Concepts and applications, Cambridge University Press. 1st ed. 